\title{
Business Focus Choices
}

\section{Focus Comes in Different Forms}

All of the SMEs included in this project adopted some form of a focus strategy. There were, however, a number of different ways of focusing. For the purpose of this research, categorizing those different ways was of great importance. Equally important to the authors was the provision of sufficient background regarding the ways in which companies arrived at their focus, and how it was then implemented. Just to state that SMEs were focused in some way was simply not sufficient to learn about this practice in depth.

The emphasis in this chapter is on the five major ways of focusing and organizing those strategies from less to more restrictive in terms of business strategy. While categorizing the different focus types, and matching companies with those categories, it became clear that some of these firms might be attributed to more than one single type of focus. For clarity, each firm was linked to one focus type only, recognizing that other observers might connect these companies and their focuses differently.

- Industry Focus

- Business Focus

- Competency Focus

- Technology Focus

- Market Focus

\section{Focusing on a Single Industry}

For most companies, the initial entry into some industrial activity provided the beginning of their focus, at least in terms of industry or product line. Many of the older companies in the sample began in a given industry sector and remained loyal to that sector for decades. This is called industry focus in the study and considered the 
least limiting or restrictive kind of focus, since it allowed management to embark on multiple businesses, leveraging different competencies or technologies, as well as target different markets. For some companies, industry focus seemed to be more of a statement of mission or purpose. The following are examples from the research.

- Sécheron started in Geneva, in 1879, with the production of some electric equipment and appliances, moving into electrical motors and generators. The nature of the industry and company did not really change over decades, although the applications and customer groups did.

- Burckhardt Compression started as a machine builder in 1844 and by 1883 had moved to building compressors, the business sector that remains its focus today.

- Ricola was started in 1930 as an extension of Emil Richterich's bakery business and was always focused on herbal sugar candy.

- LEM started on founder Jean-Pierre Etter's kitchen table in 1972; he made devices and components that measured and sensed electrical parameters, a business that the company has stayed with.

Many of the companies cited began with focusing long before the term had entered business strategy discussions. None of these firms decided from the outset that they would focus on a given activity. They produced a product that found loyal customers and eventually stayed with that business. By continuously responding to customer orders, the focus came slowly, as the result of filling repetitive orders from a similar customer group. However, these companies often went on to eventually define their focus around many additional dimensions, as will be explained later.

Some of the younger companies, launched from the 1970s to 2000, came into being by formally declaring their mission or purpose. Those statements could be interpreted as a declared industry focus at the inception of the companies' journey forward. Industry focus, while being the first set of restrictions companies imposed on themselves, did not signify a narrowly targeted focus. Industry focus still left room for many later decisions, from customers, technology, and application to value chain and even material dimensions. It will emerge later in the analysis that some companies repeatedly sharpen their focus strategies, suggesting that by taking an industry focus approach alone, they did not consider themselves sufficiently focused.

The main interest here, therefore, is not on focus by chance but instead on those practices that resulted in a deliberate managerial process to achieve a clear focus. Only if expressly stated - intentional processes of focus are identifiable - can such approaches be instructive and offer a meaningful and value-added view for other companies, executives, and entrepreneurs.

\section{Experience Leading to Business Focus}

Pursuing an industrial activity over time and accumulating extensive experience was a possible way in forging a focus. Several companies, Sefar, Plumettaz, and Jura among them, started without an articulated focus strategy. They developed their 
business exploiting opportunities along the way and eventually ended up with a clear focus.

An exceptional experience was offered by Sefar, a company that had been producing silk gauze materials for filtration and printing for about 190 years.

Sefar, earlier called Dufour \& Co., realized the opportunity offered by the rise of industrial processing, such as flour milling, that required a high-quality sieving process. As the company evolved, additional applications for its silk gauze were developed. Over time, screen-printing was added, utilizing the same production machinery.

Sefar's focus began to be articulated around its evolving core competency of producing 'highly precise holes.' Defining its focus based on its experience of almost 200 years, allowed the company to stay clear of more fashionable or glamorous segments. Fabric produced for processes where superior quality would mean longer filter life and superior filtration results led Sefar to a focus based on its accumulated experience as guidance for directions to develop. Its focus did not change over its long company history. ${ }^{1}$

Plumettaz offered the example of a company that had to evolve its focus over its history of almost 100 years. Starting in 1923 and quickly becoming a supplier of packaging machinery to Nestlé, Switzerland's largest food producer, the company was forced to refocus when the packaging machinery business was pulled in-house by Nestlé during the recession of the 1930s.

Plumettaz, looking for opportunities turned to the steep vineyards in its region and developed cultivating machines that could pull ploughs upward through the vineyards. The winching mechanism developed for the ploughs led to other opportunities eventually pointing the company to capitalize on its winching expertise and allowing it to move into cable-laying application. The Plumettaz experience demonstrates that once a core competency has been developed, it can be moved into other applications areas giving the company a new focus beyond the competency alone. ${ }^{2}$

Whereas the two previous examples show companies that either stayed with, or evolved, their focus over time, Jura demonstrates the experience of a deliberate shift in focus. Founded by Leo Henzirohs, who was a tinkerer concentrating on electrical appliances for home use, the company grew beyond coffee machines by adding irons, toasters, and even refrigerators and washing machines, all for the Swiss market.

When increasing international competition caused Jura to lose competitiveness, a new management team focused on its best-selling product, an espresso machine for home use, developed a new model and made this new line its best-selling and ultimately globally successful product. The exercise, which resulted in substantially reducing the product line and focusing on a single family of automated espresso machines for home use, represented an abrupt departure from Jura's previous business practices of offering a full line of home appliances. $^{3}$

\footnotetext{
${ }^{1}$ Adapted from Sefar company profile.

${ }^{2}$ Adapted from Plumettaz company profile.

${ }^{3}$ Adapted from Jura company profile.
} 
The examples of Sefar, Plumettaz, and Jura demonstrated that there were not only different pathways towards reaching a business focus strategy; for example, inherited focus to respond to market changes or deliberate focus for greater competitiveness, but also different types of focus within those business strategies. While Sefar focused on a core competence based upon its production technology (holes), Plumettaz focused on the exploitation of a technology (winching) and Jura concentrated on a single machine and application (making espresso).

Consequently, the next section will offer a typology of focus, categorizing the different ways companies have found focus and describing some of their experiences with them. As indicated before, the authors recognize that any of these companies could also be seen as pursuing more than a single type of focus. For clarity's sake, the one company/one focus type representation was chosen.

\section{Focusing Around Core Competency}

Core competences have been a management concern ever since the concept was introduced by Prahalad and Hamel in 1990. The authors defined core competence as a "harmonized combination of multiple resources and skills that distinguish a firm in the marketplace." Core competencies should provide access to a wide variety of markets, make a significant contribution to customer benefits through a product and be difficult for competitors to imitate. ${ }^{4}$

Among the companies researched for this book, several examples were found where a core competence served as the basis for building an entire company. The Prahalad and Hamel criteria were clearly met by two of our documented companies, namely Sefar and maxon.

Sefar leveraged its core competence of 'highly precise holes' into a large number of customer or industry application, all from a common technological base. Marketing its technical precision fabrics to a large number of user industries, such as electronics, graphics, medical, automotive, food, pharmaceuticals, aerospace, mining, refining and architecture, the company has managed to leverage a single technology into multiple customers groups. ${ }^{5}$

At maxon, emerging from a business of supplying components for electric shavers, a design team developed a range of small electric DC motors, including a patented process for an ironless rotor which doubled the efficiency of available motors and extended their product service life. The final step towards mass production came with the mastery and development of a special rhombic winding technology and the corresponding winding machine, which also became a patented process. ${ }^{6}$ maxon's rhombic winding technology, and the development of automated winding equipment, proved to be a major breakthrough and a process that could not be copied by competitors, because the manufacturing equipment was not available on the open market. The resulting electric motors found their way into a large number of

\footnotetext{
${ }^{4}$ Prahalad CK, Hamel G (1990) The core competence of the corporation. Harvard Business Review, 68(3): 79-91.

${ }^{5}$ Adapted from Sefar company profile.

${ }^{6}$ Adapted from maxon company profile.
} 
industry applications, from aerospace to medical, automotive, communication, consumer, instrumentation and industrial automation.

Other examples among the researched companies, leveraging a core competence include the following.

- Komax: wire stripping

- Plaston: injection molding

- Burckhardt: compression

- Geistlich: bone processing

- Plumettaz: winching

- Sefar: highly precise holes

- Jura: espresso machines

The success of this focusing strategy has depended on a company's ability to leverage its competence and technology into multiple applications, putting great emphasis on a skilled marketing and sales force that can reach into many application industries. To the extent that a company can be successful at establishing such a sales expertise, a higher business volume can be pursued, which will drive profitability and the ability to withstand competitive pressures.

\section{Pursuing a Technology Focus}

When companies define their focus strategy around a given technology, the resulting approach and business configuration differs. Technology is usually defined as applied science and may combine a number of tools, equipment, instruments, devices, and systematic skills to produce a desired effect. The acquisition of such a technology often accrues over time, can be proprietary, and can build a significant hurdle for others wishing to enter the same technological space. Mastering a technology is thus broader than just a product concept, is different from understanding a certain industry or customer group, and is usually part of a company's fundamental DNA.

Since mastering and maintaining a cutting-edge technology requires considerable resources, companies that pursue this course invariably attempt to monetize their technology into multiple markets or applications to maximize return. From the companies that took part in this research, two of which offer a clear example of this type of focus are featured here. Geneva-based LEM, although its products invisible to consumer's eyes, were nonetheless indispensable regarding a full range of power electronic applications. It was founded as a limited company in 1972, under the name of Liaisons Electroniques-Mécaniques LEM SA. In 45 years LEM grew into a global company with sales of CHF 321 million (2019) with a single-minded focus on exploiting its technology around power electronics. 
LEM was a manufacturer of transducers for measuring and sensing of electrical parameters, such as current and voltage, used in a broad range of applications. Users relied on LEM for functionality in a wide range of applications, from variable speed drives for electric motors to power supplies for industrial electrical equipment. LEM transducers were used in AC/DC converters, uninterrupted power supply systems, micro turbines for wind and solar power generation and, increasingly, in a full range of electrical and battery applications for automotive industry. By monitoring electric current and voltage, electronic systems could optimize use and regulation of power, ensured safe operation and identified problems before they caused equipment failures.

Although LEM was focused on selling components, or transducers, the company had moved into many industry sectors where company or product-specific components were sold. Railway and trackside applications were the first segments penetrated. Later, industry applications, such as for robots for energy and automation, eclipsed the rail sector, followed by a wave of renewable energy applications in solar and wind. More recently, the automotive sector was gaining in importance. Given their different economic cycles (from early to late cycles), the variety of sectors provided for diversified businesses and stable sales while maintaining product focus. ${ }^{7}$

LEM's approach then was to exploit its technology in a multitude of application niches. By emphasizing standard components and placing them into a catalog, the company could offer a large number of components for different applications based on its main technology. This technology was at the base of the company since its creation in 1972 and continued to bear superior economic rewards.

EAO's journey to find its technology focus differed from LEM's. EAO had actually started in 1947 making electrical transformers when a customer brought a new idea to the attention of the company's founders.

One day, an electrical cabinet maker who sourced transformer from EAO, told them about problems he had with switches in his cabinets. They saw an interesting business opportunity since one of the founders knew something about switches and push buttons from his own work experience. Approaching the challenge with an innovative spirit, they developed a push button made from new plastic materials, with a small lamp fully incorporated, and finally miniaturized it to a new standard compact size. There were no such products with that combination of features on the market in 1958 .

The lighted buttons found success, and the reaction of the EAO founders was: "Let's go and make some more." The suggestion of the electrical cabinet maker eventually led products around human-machine interfaces (HMI) that became the dominant business of EAO. Technologically, HMI buttons were at the intersection of mechatronics, electrical, mechanical, and software technologies. The plastic components had to be molded to a precision of $1 / 100 \mathrm{~mm}$, placing great demands on molding operation and miniaturization. ${ }^{8}$

EAO grew as a company to CHF 130 million in sales producing some 30 million push buttons annually. These products were sold into a multitude of application segments, including railways, transportation, automotive, and machine automation. EAO has become exclusively focused on exploiting its technology for HMI applications, divesting earlier business segments.

\footnotetext{
${ }^{7}$ Adapted from LEM company profile.

${ }^{8}$ Adapted from EAO company profile.
} 
Other technology-focused companies include the following.

- Filtrox on depth filtration technology

- FISBA on optical technology

- u-blox for positioning technology

- LNS with its bar feeding technology

- Mikrop on optical technology

Companies pursuing a technology strategy, as will be seen later, found easy entrance into exploiting their technologies into a platform leading to multiple product variations and multiple application segments. Doing this off a single technology makes for a narrowing of focus.

\section{Focusing on a Single Market}

Some of the SME companies decided to concentrate on a certain market. Markets are more narrowly defined than industries and allow for a concentration of efforts. Companies that follow this approach serve their markets with a bundle of products but, essentially, all of them focused on a selected target market.

During most of its long history, Sécheron had concentrated on equipment for the electrification of the Swiss Federal Railways, or SBB. The company focused on the electric traction of rolling stock, railways, trams, and metros. All of its three main businesses were thus directed at the rail business where the company could leverage its strong heritage in this sector.

Sécheron's component business involved the design and manufacturing of standard and customized components, as well as more complex subsystems, where the company integrated its own, or third-party, components into compact high-voltage enclosures convenient to supply and easy to install.

In the systems business, Sécheron had captured the position as the world's leading supplier of electrical equipment for DC traction substations with an installed base across many countries.

The business for on-board electronics was the smallest of the three businesses. Operated under the Hasler brand, for more than 120 years, the company was the market leader for speed acquisition systems, for speed displays and train data recorders. The market approach differed from the other Sécheron businesses in that it required a different sales and distribution network but was aimed at the same market, namely controlling rolling stock. ${ }^{9}$

Sécheron, and its three operating divisions, were all focused on a single market, namely for electric rolling stock or trains. The company was offering, however, a large bundle of products for this market, combining different technologies.

Felco, the producer of pruning shears for the agricultural market, with special emphasis on wine growers, offered another example of a single market focus. The

\footnotetext{
${ }^{9}$ Adapted from Sécheron Groupe company profile.
} 
agricultural market used pruning shears for a number of activities, including pruning trees. With a focus on this market, Felco offered a large number of pruning products, from single hand to dual hand, from manual to power-assisted, but the main purpose always being used in an agricultural environment.

As the Felco story goes, a wine grower approached Flisch asking for a hand-held pruner for his vines. Since he could make such good tools, maybe he could also make one for his use in the vineyard. The first design, named Model 1, made of forged aluminium, interchangeable parts and of high durability, became an immediate success and other wine growers asked for the same. Before long, a growing business developed for these pruning shears that have become the leading product for Felco. The follow-on model, Felco 2, looked the same as the original model but was produced differently. It came coated with the now classic red handles. The Model 2 remained the company's bestseller since 1948 to this day, producing 3,000 per day, retailing at CHF 50, approximately three times the price of cheaper imports from Asia copying Felco's design. ${ }^{10}$

The Felco experience not only documents a strategy for a single market, but also shows that this concentration can reap considerable rewards when the business expands globally. However, it does not mean that an industry focus on agriculture or vineyards would result in sales to this market alone. The company's experience shows that its products were used in segments other than winegrowing and even for non-agricultural purposes. However, true to its focus strategy, the company usually abstained from exploiting such outliers.

Impressive is Selectron's path to its focus on in-train automation. The company at one time served three different markets, namely factory automation, building controls, and train electronics, yielding no significant synergies. Through efforts of concentration, Selectron navigated its way to focus on train electronics as its single market, eventually phasing out the other two.

Selectron's initial competitiveness as a supplier to the Swiss Railway was based upon its willingness to varnish the electronic controls and select ruggedized components to meet the stringent requirements for train operation. If the PLCs were not varnished, reliability of the equipment was not assured. Condensation caused by temperature differences as a result of tunnels, as well as dust collected from steady use, could result in short circuits in the system. Major automation suppliers were not interested in taking this extra step, forcing the railway operator to use heavy protection boxes instead. New European regulations (EN 50155) required that electronic controls withstand operating temperatures from $-40 \mathrm{C}$ to $+85 \mathrm{C}$, compared to $0 \mathrm{C}$ to $+50 \mathrm{C}$ for normal applications. Controls had to be vibration and shock proof, protected from interference and withstand humidity in tunnels, all of which would not be achieved from standard control suppliers.

The fact that in the past, to compete in the machine tool automation segment, the company had consistently reduced the size of its controllers helped to make its products fit into the tight spaces of railway cars. Efforts were concentrated on the railway automation segment since the Swiss Railways had placed a five-year contract to supply controls units for a large refurbishing contract for older trains. Stopping efforts in off-target segments freed

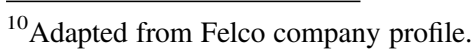


capacity in the development and sales departments needed to drive the effort in the railway segment labeled 'In-Train Automation.'11

Accounting for just $15 \%$ of sales in 2000 , Selectron managed to grow a small train refurbishing business for the Swiss Railway of about CHF 2.5 million into a growing company of CHF 75 million in 2018, occupying a significant position in the international in-train control market.

Other single market-focused companies included the following.

- Pilatus on the aircraft market

- Thermoplan on the gastro market

- Geistlich Pharma on the dental market

- Kuhn Rikon on the kitchen and cooking market

- Caran d'Ache on the market for writing and drawing

Focusing on a single market provides, and necessitates, in-depth knowledge of the operating conditions of a company's customers. Accumulating such deep understanding across a number of markets would dilute attention and spread scarce market resources across too many targets.

Five different ways of focusing have been described here; focus on either an industry, a business, a competency, a technology, or on a market. Each of these paths has its own value and will lead companies to advance into different directions. The next chapter will introduce a different focus category, namely the concept of customer franchise - a concentration on a single customer or client group-and will illustrate why this offers yet another perspective to these companies.

Open Access This chapter is licensed under the terms of the Creative Commons Attribution 4.0 International License (http://creativecommons.org/licenses/by/4.0/), which permits use, sharing, adaptation, distribution and reproduction in any medium or format, as long as you give appropriate credit to the original author(s) and the source, provide a link to the Creative Commons license and indicate if changes were made.

The images or other third party material in this chapter are included in the chapter's Creative Commons license, unless indicated otherwise in a credit line to the material. If material is not included in the chapter's Creative Commons license and your intended use is not permitted by statutory regulation or exceeds the permitted use, you will need to obtain permission directly from the copyright holder.

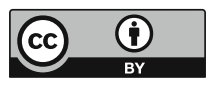

${ }^{11}$ Adapted from Selectron company profile. 